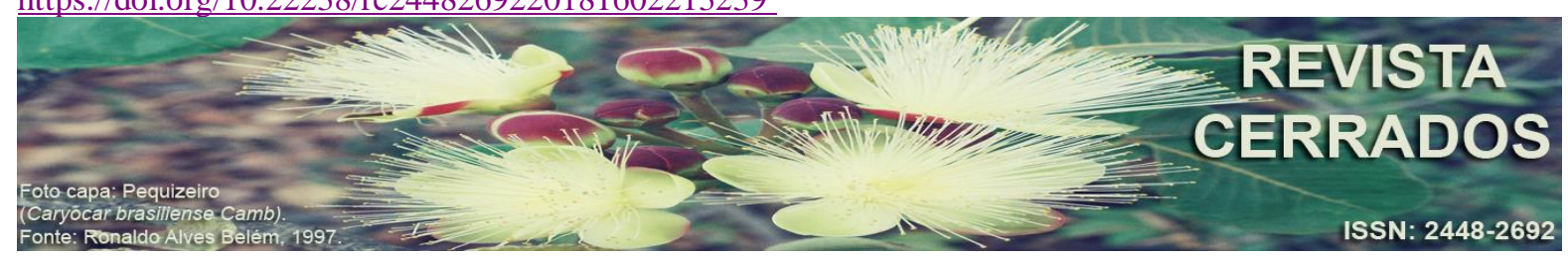

\title{
PAISAGENS E EMPIRISMO, ELEMENTOS CONSTITUTIVOS DAS EXPERIÊNCIAS EM GEOGRAFIA: um estudo sobre as veredas do chapadão de Catalão (Goiás)
}

\section{LANDSCAPES AND EMPIRISM, CONSTITUTIVE ELEMENTS OF EXPERIENCES IN GEOGRAPHY: a study on the paths of chapadão de Catalão (Goiás)}

\section{PAISAJES Y EMPIRISMO, ELEMENTOS CONSTITUTIVOS DE LAS EXPERIENCIAS EN GEOGRAFÍA: un estudio sobre las veredas del chapadón de Catalão (Goiás)}

\author{
Jean Carlos Vieira Santos \\ Universidade Estadual de Goiás - UEG \\ E-mail: 〈svcjean@yahoo.com.br〉. \\ Vandervilson Alves Carneiro \\ Universidade Estadual de Goiás - UEG \\ E-mail: <vandervilson.carneiro@ueg.br>. \\ Lorranne Gomes da Silva \\ Universidade Estadual de Goiás - UEG \\ E-mail: 〈lorrannegomes@gmail.com>.

\section{Vinícius Polzin Druciaki} \\ Universidade Estadual de Goiás - UEG \\ E-mail: 〈geomobilidade@gmail.com>.
}

\begin{abstract}
RESUMO
O presente artigo apresenta os resultados de um trabalho de campo que teve como área de estudo as veredas do chapadão de Catalão (Goiás, Brasil), nos municípios de Goiandira, Catalão e Ipameri, onde as mudanças no uso do solo são constantes, pois as chapadas são formas de relevo mecanizadas, adubadas e irrigadas que sofreram grande emprego de agrotóxicos nas últimas décadas. Partiu-se do levantamento bibliográfico, fotográfico e de observações empíricas, sendo que o desenvolvimento desta investigação vem ao encontro do método e das técnicas das pesquisas qualitativas que enfatizam a participação dos pesquisadores no contexto estudado. Entre os conceitos trabalhados neste texto estão paisagem, percepção e veredas, com destaque para as obras de Bertrand (1968), Ab'Sáber

Licenciada sob Creative Commons (cc) $1 \mathrm{EY}-\mathrm{Ha}-\mathrm{NL}$

Revista Cerrados, Departamento de Geociências e Programa de Pós-Graduação em Geografia (UNIMONTES)
\end{abstract}


SANTOS, J. C. V.; CARNEIRO, V. A.; SILVA, L. G.; DRUCIAKI, V. P.

Paisagens e empirismo, elementos constitutivos das experiências em Geografia: um estudo sobre as veredas do chapadão de Catalão (Goiás)

(1969), Rougerie (1971), Bernaldez (1981), Ribeiro (1989), Christofoletti (1993), Santos (1997), Feltran Filho (1997), Ferreira (2006), entre outros. Esses teóricos mostram que, ao analisar uma paisagem, é preciso considerar fatores condicionados à ecologia, como usos do solo, percepção, compreensão e gerenciamento dela.

Palavras-chave: Trabalho de Campo. Região. Cerrado. Drenagem. Agronegócio.

\begin{abstract}
The present article presents the results of a fieldwork that had the paths of chapadão de Catalão (Goiás, Brazil) as a study area, in the municipalities of Goiandira, Catalão and Ipameri, where changes in land use are constant, since the plated are mechanized, fertilized and irrigated forms of relief that have suffered great use of pesticides in the last decades. It was based on the bibliographical, photographic and empirical observations, given that the development of this research meets the method and techniques of qualitative research which emphasizes the participation of researchers in the studied context. Among the concepts worked on in this text are landscape, perception and paths, with na emphasis on the works of Bertrand (1968), Ab’Sáber (1969), Rougerie (1971), Bernaldez (1981), Ribeiro (1989), Christofoletti (1993), Santos (1997), Feltran Filho (1997), Ferreira (2006), among others. These theorists show that when a landscape is analyzed, it is necessary to consider factors that are conditioned to ecology, such as land uses, perception, understanding and management of it.
\end{abstract}

Keywords: Fieldwork. Region. Cerrado. Drainage. Agribusiness.

\title{
RESUMEN
}

El presente artículo presenta los resultados de un trabajo de campo que tuvo como área de estudio las veredas del chapadão de Catalão (Goiás), en los municipios de Goiandira, Catalán e Ipameri, donde los cambios en el uso del suelo son constantes, pues las las chapadas son formas de relieve que fueron mecanizadas, abonadas, irrigadas y sufrieron un gran empleo de agrotóxicos en las últimas décadas. Para la producción del mismo, se partió del levantamiento bibliográfico, fotográfico y observaciones empíricas. El desarrollo de esta investigación viene al encuentro del método y de las técnicas de las investigaciones cualitativas, que enfatiza la participación de los investigadores, en el contexto investigado. En el caso de las obras de Bertrand (1968), Ab’Sáber (1969), Rougerie (1971), Bernaldez (1981), Ribeiro (1989), Christofoletti (1993), Santos (1997), Feltran Filho (1997), Ferreira (2006), entre otros. Estos teóricos muestran que al analizar un paisaje, tenemos que considerar una serie de factores que están condicionados a la ecología, usos del suelo, percepción, comprensión y gestión de la misma.

Palabras clave: Trabajo de campo. Región. Cerrado. Drenaje. Agroindustria. 
SANTOS, J. C. V.; CARNEIRO, V. A.; SILVA, L. G.; DRUCIAKI, V. P.

Paisagens e empirismo, elementos constitutivos das experiências em Geografia: um estudo sobre as veredas do chapadão de Catalão (Goiás)

\section{INTRODUÇÃO}

O presente artigo se refere ao trabalho de campo que teve como área de estudo as veredas do chapadão de Cataãão (Goiás), nos municípios de Goiandira, Ipameri e Catalão, nas proximidades da rodovia GO-213, que liga este último a Caldas Novas, na bacia hidrográfica do Rio Paranaíba. Tais locais comportam exemplares das principais paisagens do cerrado brasileiro, em que as mudanças no uso do solo são constantes. De acordo com Ab'Sáber (2003, p. 19), o domínio do cerrado é uma:

Área paisagística ecológica resistente às ações predatórias rotineiras, a despeito mesmo de apresentar casos locais berrantes de ravinamentos. A utilização imediata e pouco racional dos capões de mata "matos grossos" eliminou a cobertura vegetal e estragou os solos de modo quase irreversível (caso dos capões de matas situados no norte de Anápolis e do extenso mato grosso de Goiás, na região de Ceres).

É notável que o cerrado goiano produz quantidade considerável de grãos, no entanto, já foi considerada uma paisagem de pouco valor comercial. As chapadas foram particularmente rechaçadas pela maioria dos proprietários pecuaristas da região, que preferiam ocupar as vertentes inclinadas no passado. Hoje, as formas de relevo mecanizadas, adubadas e irrigadas com agrotóxicos passaram a ser cobiçadas pela modernização agrícola, sendo possível visualizar essa prática na região do chapadão de Catalão. A área ocupada pelo cerrado no território brasileiro é caracterizada desta maneira por Aguiar, Machado e Marinho Filho (2004, p. 18):

O Cerrado ocupa uma área de aproximadamente 1,8 milhão de km quadrados (cerca de $21 \%$ do território brasileiro) e corta diagonalmente o país no sentido nordestesudoeste. A área central do Cerrado limita-se quase com todos os biomas, à exceção dos Campos Sulinos e os ecossistemas costeiro e marinho, mas existem também encraves de Cerrado na Amazônia, na Caatinga e na Mata Atlântica (por exemplo, na região de Barbacena, MG). Tais áreas são remanescentes de um processo histórico e dinâmico de contração e expansão das áreas de Cerrado e de florestas, provocado por alterações climáticas ocorridas no passado.

Os autores citados sublinham que, apesar da imprecisão dos dados e da divergência entre pesquisadores, existem aproximadamente sete mil espécies de angiospermas no cerrado, mas esse número pode chegar a dez mil. Nesse contexto, 35\% das plantas do bioma são típicas da formação de cerrado (sentido restrito), 30\% das espécies vegetais pertencem à mata de galeria, 25\% às áreas campestres e $10 \%$ ainda não foram classificadas. 
SANTOS, J. C. V.; CARNEIRO, V. A.; SILVA, L. G.; DRUCIAKI, V. P.

Paisagens e empirismo, elementos constitutivos das experiências em Geografia: um estudo sobre as veredas do chapadão de Catalão (Goiás)

Entre os mamíferos, a riqueza desse bioma pode chegar a 199 espécies, e o nível de endemismo é considerado baixo, se comparado aos outros grupos, pois somente $8 \%$ das espécies são exclusivas. No caso das aves, a riqueza estimada é de 837 espécies (embora descrições de novas formas ainda estejam acontecendo), e a diversidade de répteis também é expressiva (AGUIAR; MACHADO; MARINHO FILHO, 2004).

Os números apresentados têm como finalidade mostrar a biodiversidade do cerrado, em que a agricultura e pecuária desenvolvidas de forma desordenada estão comprometendo a manutenção de tal bioma. Outros fatores relevantes no município de Catalão são considerados como uma ameaça - as áreas minerárias e os reservatórios hidrelétricos nos principais rios -, com destaque para os projetos nas drenagens do São Marcos e do Paranaíba.

Interferências antrópicas têm provocado impactos negativos ao ambiente, como a retirada da cobertura vegetal, pisoteio de animais de criação, plantações na beira dos rios, acúmulo e despejo de rejeitos e partículas de solos contaminados pelos resíduos [...]. Esses resíduos químicos e orgânicos contaminam as águas e os sedimentos de qualquer curso fluvial (ARAÚJO; FREITAS; BAGGIO FILHO, 2016, p. 92).

Diante disso, o compromisso com o desenvolvimento ordenado em áreas como o cerrado é imprescindível à preservação e à conservação da biodiversidade, sobretudo no estado de Goiás, onde os aspectos fitofisionômicos desse bioma predominam. É fundamental uma gestão sistêmica e responsável, pois na região dos cerrados estão as principais nascentes das bacias hidrográficas brasileiras.

Diante desse contexto de caracterização geral do bioma cerrado, o presente artigo tem como foco de estudo as áreas de veredas, definidas pelas legislações federal e estadual como paisagens de Áreas de Preservação Permanentes (APPs). Partiu-se do levantamento bibliográfico, fotográfico e de observações empíricas. O desenvolvimento dessa investigação vem ao encontro do método e das técnicas das pesquisas qualitativas, que enfatizam a participação dos pesquisadores no contexto estudado. Desse modo, Demo (1998) destaca que tal tipo de pesquisa é uma linha de investigação concebida conforme perspectiva compreensiva. Várias técnicas são utilizadas, como observações, entrevistas, pesquisa-ação, discurso do sujeito coletivo, entre outras.

Na pesquisa qualitativa, é importante a imersão do pesquisador no contexto, de forma a interpretar e interagir com o objeto estudado; logo, foram fundamentais as 
SANTOS, J. C. V.; CARNEIRO, V. A.; SILVA, L. G.; DRUCIAKI, V. P.

Paisagens e empirismo, elementos constitutivos das experiências em Geografia: um estudo sobre as veredas do chapadão de Catalão (Goiás)

observações de campo, ou seja, os trabalhos empíricos desenvolvidos. É importante frisar que o método qualitativo se voltou a pensar o trabalho não apenas no campo dos resultados, como também na realidade encontrada nas chapadas dos municípios da região investigada.

\section{PAISAGEM, PERCEPÇÃO E VEREDAS: ALGUMAS ABORDAGENS CONCEITUAIS}

Um dos principais objetivos deste trabalho empírico se refere a compreender o processo de produção da natureza, as percepções, as atitudes, os valores atribuídos às paisagens de cerrado e os conflitos existentes; assim, há a necessidade de discutir os conceitos de paisagem, percepção e vereda. A primeira definição de paisagem vem do final do século XX, em que Moraes (1990) considerava que diversos autores viam a Geografia como o estudo da paisagem. Para o autor supracitado, a análise geográfica estaria restrita aos aspectos visíveis do real. A paisagem posta como objeto específico da Geografia é uma associação de múltiplos fenômenos, o que mantém a concepção de ciência de síntese, que trabalha com dados das demais ciências. Tal perspectiva apresenta duas variantes para a apreensão da paisagem:

[...] uma, mantendo a tônica descritiva, se deteria na enumeração dos elementos presentes e na discussão das formas - daí ser denominada de morfológica. A outra se preocuparia mais com a relação entre os elementos e com a dinâmica destes, apontando para um estudo da fisiologia, isto é, do funcionamento da paisagem (MORAES, 1990, p. 15).

Nessa abordagem, a fisiologia da paisagem se fundamenta na Biologia, em particular na ideia de organismo; por conseguinte, a paisagem seria um organismo com funções vitais e elementos que interagem. À Geografia caberia buscar inter-relações entre fenômenos de qualidades distintas que coabitam determinada porção do espaço terrestre. Ao discutir essas informações sob o viés do raciocínio geográfico, Christofoletti (1993) assevera que o uso do termo "paisagem", na linha da Geografia, se origina na ciência geográfica alemã. Por sua vez, Rougerie (1971, p. 7) diz que:

É cômodo definir a Geografia como o estudo das paisagens. Não há de faltar, por certo, quem venha apontar a imprecisão e a feição qualitativa, ou mesmo "artística", da expressão; outros, movidos por um desejo de exatidão, hão de preferir a cisão da 
SANTOS, J. C. V.; CARNEIRO, V. A.; SILVA, L. G.; DRUCIAKI, V. P.

Paisagens e empirismo, elementos constitutivos das experiências em Geografia: um estudo sobre as veredas do chapadão de Catalão (Goiás)

realidade e falarão em paisagens morfológicas, em paisagens vegetais, em paisagens agrárias ou urbanas [...]. Contudo, como a Geografia também consiste em localizar fatos, em apreender as diferenciações do espaço terrestre e em comparar conjuntos desvendando seu dinamismo interno e suas relações recíprocas, poderemos nos considerar no âmago desta ciência quando nos declaramos favoráveis à expressão material de tais diferenciações: as paisagens.

$\mathrm{O}$ mesmo autor comenta que a paisagem integra igualmente o homem e as eventuais depredações efetuadas por ele no passado, em se tratando do tapete natural. Nesse sentido, pode-se entender que a paisagem é uma constituição de um todo percebido por vários sentidos cujas relações causais, para serem compreendidas, deverão ser analisadas uma por uma, tal como as interações do complexo vivo formado por ela.

$\mathrm{Na}$ trajetória histórica do conceito, Sturza (1999) lembra que a palavra "paisagem" foi incorporada ao léxico técnico pela primeira vez em 1805, por Hommeyer. Seu uso nos diversos ramos do conhecimento resultou em inúmeras interpretações e significados constantes em verbetes dos dicionários técnicos ou não. Conforme Bernaldez (1981, p. 1), “[...] es difícil dar una explicación cumplida de las acepciones y origen del término paisaje. La multiplicidad de acepciones puede dar lugar a confusión".

Tanto Maciel e Lima (2011) como Bolós (1981) asseguram que a paisagem integrada é um campo geográfico, uma unidade espacial, em que a morfologia agrega complexa inter-relação entre os elementos da fisiografia, sob a ação constante da sociedade que a transforma cotidianamente. Ademais, Coll e Teberosky (2000, p. 100) dizem que "[...] as cidades, as aldeias indígenas, os campos cultivados, as praias, os rios e as florestas formam paisagens". Em cada paisagem há diferentes formas, cores e sons resultantes das construções das paisagens e das modificações do meio onde os seres vivem. Nesse contexto, Santos (1997, p. 61) define o termo "paisagem" como:

Tudo aquilo que nós vemos, que nossa visão alcança, é a paisagem. Esta pode ser definida como o domínio do visível, aquilo que a vista abarca. Não é formada apenas de volume, mas também de cores, movimentos, odores, sons, etc. Nossa visão depende da localização em que está, se no chão, em um andar de baixo ou alto de um edifício, num miradouro estratégico, num avião [...]. A paisagem toma escalas diferentes e assoma diversamente aos nossos olhos [...].

Sobre a abordagem apresentada, vale destacar o entendimento de Bertrand (1968, p. 2), citado por vários pensadores como uma definição clássica e de grande influência em pesquisas desenvolvidas no campo da Geografia: 
SANTOS, J. C. V.; CARNEIRO, V. A.; SILVA, L. G.; DRUCIAKI, V. P.

Paisagens e empirismo, elementos constitutivos das experiências em Geografia: um estudo sobre as veredas do chapadão de Catalão (Goiás)

Paisagem não é a simples adição de elementos geográficos disparatados. É, numa determinada porção do espaço, o resultado da combinação dinâmica, portanto instável, de elementos físicos, biológicos e antrópicos que fazem da paisagem um conjunto único e indissociável, em perpétua evolução. Estudar uma paisagem é antes de tudo apresentar um problema de método.

Nota-se que a noção de escala é indissociável do estudo das paisagens. Sobretudo quando o estudo é desenvolvido no âmbito da Geografia e suas áreas afins, não se podem perder os referenciais de pesquisas, mesmo que se utilize apenas a noção do conteúdo (BERTRAND, 1968). A abordagem de Bertrand (1968) é mais ampla, no sentido de conceituar o termo "paisagem" ao interagir os fatores naturais com as ações do homem. Ele afirma que as paisagens ditas "físicas" são quase sempre remodeladas pela exploração antrópica, e a divisão em parcelas, territórios, comunidades, quarteirões e pays ${ }^{1}$ diz respeito a um dos critérios essenciais da taxonomia das paisagens. Esse autor considera a paisagem como uma entidade global, ao admitir que os elementos que a constituem participam de uma dinâmica comum que não corresponde obrigatoriamente à evolução de cada um, tomado de maneira separada.

$\mathrm{Na}$ linha clássica, mas com abordagem da fisiologia da paisagem, Ab’Sáber (1969) destaca que esta deve se apoiar, pelo menos, nos seguintes conhecimentos: a sucessão habitual do tempo, a atuação dos fatos climáticos não habituais, a hidrodinâmica global da área e os processos biogênicos e químicos inter-relacionados:

Se é que uma paisagem tropical não evolui a partir de uma estaca zero, completamente despida de solos e de vegetação, mas sim evolui ou se modifica a partir de toda a sua riqueza superficial de produtos de intemperismo, de solos e de cobertura vegetal, é evidente que o seu relevo atual comporta um saldo de interferências que somente pode ser compreendido à custa de uma investigação minuciosa dos seus depósitos superficiais. $\mathrm{Na}$ realidade, custou muito para se compreender que as bases rochosas da paisagem respondem apenas por uma certa ossatura topográfica, e, que, na realidade são os processos morfoclimáticos sucessivos que realmente modelam e criam feições próprias no relevo (AB'SÁBER, 1969, p. 4).

$\mathrm{O}$ autor considera ainda que o estudo sobre a fisiologia da paisagem precisa se pautar em informes prolongados, obtidos em tempos representativos para a área e incluindo observações realizadas em momentos críticos para a atividade morfogênica. Ribeiro (1989) deixa claro que o estudo da paisagem deve extrapolar a observação e a descrição dos

\footnotetext{
${ }^{1}$ Paysage.
} 
SANTOS, J. C. V.; CARNEIRO, V. A.; SILVA, L. G.; DRUCIAKI, V. P.

Paisagens e empirismo, elementos constitutivos das experiências em Geografia: um estudo sobre as veredas do chapadão de Catalão (Goiás)

fenômenos. Por trás das aparências, é necessário buscar os mecanismos genéticos e dinâmicos que provocam as incessantes transformações das paisagens, essenciais como condição da própria existência. O mesmo autor avança nessa conceituação com a seguinte abordagem:

Compreender o mosaico das paisagens de um determinado território é desvendar não apenas o significado dos sinais exteriores percebidos pelo sentido da visão. É, principalmente, entender os processos estruturadores e dinâmicos da própria realidade percebida. Entretanto, não basta o entendimento das aparências, ou seja, da dimensão imediata desta realidade. É necessário ir além das aparências e penetrar na essência dos fenômenos para se buscar as causas da própria existência destes (RIBEIRO, 1989, p. 1).

Devido à formação na área da Geografia Física, Ribeiro (1989) faz uma análise do estudo das paisagens, mas sem se esquecer do lado humanista. Sobre a temática elencada, nas palavras de Cruz (1998, p. 236), não é somente a diversidade biológica que compõe uma paisagem:

Há também diversidade nas suas bases rochosas e seus materiais correlatos, nas suas formas de relevo e topografia, na zonalidade e nas características dos seus episódios climáticos, nas águas pluviais, fluviais e marinhas em movimento e envolvimento dinâmico, além da capacidade de diversidade de pensamento com que somos capazes de entendê-la. O espaço físico é a base na qual se assenta e se desenvolve, num elo íntimo, a humanidade, suas obras e suas realizações. Esse espaço é, antes de tudo, ecológico e real. Não é plano nem uniforme: o "chão" não é liso. Dependendo da escala, na visão horizontal de uma paisagem urbana, p.ex., seus edifícios altos e compactos dão a impressão de esconder a diversidade do relevo e topografia, dos canais e nichos de nascentes desmatados, ressecados, aterrados, cimentados, asfaltados.

Nesse entremeio, Ross (2000, p. 11-12) postula que:

[...] as unidades de paisagens naturais se diferenciam pelo relevo, clima, cobertura vegetal, solos ou até mesmo pelo arranjo estrutural e do tipo de litologia ou por apenas um desses componentes. [...] o entendimento do relevo passa por tanto pela compreensão de uma coisa maior que é a paisagem como um todo.

A Geomorfologia é fundamental neste trabalho, principalmente nas apresentações dos resultados de campo, em que serão definidos os tipos de veredas ${ }^{2}$. Vale ressaltar que elas estão intimamente associadas às formas de relevo. Em se tratando da

\footnotetext{
${ }^{2}$ Tecnicamente, as veredas se constituem num subsistema típico do cerrado brasileiro. Individualizam-se por possuírem solos heteromórficos, argilosos, geralmente orgânicos, como brejos estacionais e/ou permanentes, quase sempre com a presença de buritizais (Mauritia vinifera e/ou Mauritia flexuosa) e floresta estacional arbóreo-arbustiva, com a presença de fauna variada, configuradas em terrenos depressionários dos chapadões e áreas periféricas - ambiente ripário (FERREIRA, 2005, p. 2).
} 
SANTOS, J. C. V.; CARNEIRO, V. A.; SILVA, L. G.; DRUCIAKI, V. P.

Paisagens e empirismo, elementos constitutivos das experiências em Geografia: um estudo sobre as veredas do chapadão de Catalão (Goiás)

importância das bases rochosas, ou seja, da Geologia na estruturação das paisagens, o geógrafo Feltran Filho (1997, p. 10) cita que:

[...] aspectos físicos como a topografia, as formas de vertentes, os solos, a rede de drenagem, os processos erosivos, a distribuição e quantidade de afloramentos e, mesmo indiretamente, os tipos de vegetação e as temperaturas, se refletem na organização da paisagem e na sua ocupação.

No enfoque da pedopaisagem, Curi (1993, p. 60) conceitua "paisagem" da seguinte forma:

Todas as características naturais, tais como campos, colinas, florestas, água, etc., que distinguem uma parte da superfície da terra de outra. Normalmente, considera-se como sendo aquela porção de terra ou território, que um observador pode enxergar em uma única visada, incluindo todas as suas características naturais. A expressão pedopaisagem (soilscape, em inglês) denota a qualidade pedológica do terreno.

Essas palavras e as ideias dos diversos autores salientam a relevância de conceituar o termo "paisagem" sob diferentes linhas de pensamento, mostrando que tal expressão, nas diversas ciências e principalmente na Geografia, engloba os sistemas sociais, culturais, econômicos e naturais. Para contribuir com essa etapa, mas sem esgotar o assunto em questão, há os apontamentos de Ab’Sáber (1982, p. 31) que, apesar de terem sido publicados há mais de duas décadas, ainda continuam atuais:

Os que se iniciam na descrição das paisagens naturais, assim como os que pretendem usar uma terminologia geográfica adequada, devem conhecer alguns termos chaves, de caráter puramente topográfico, indispensáveis para uma boa e concisa descrição geográfico-física. [...] Os geógrafos, por sua vez, têm o espaço geográfico inteiro para estudar, descrever e interpretar. Seu campo de estudo tem a superposição de construções da natureza e de construções humanas. É um tecido grandioso de organização complexa. Daí a necessidade de se obter uma terminologia mínima, suficientemente ampla e variada para atender às bases territoriais do teatro geográfico das atividades humanas.

Em complemento à transição do termo "paisagem" para os conceitos de "percepção" e "vereda" - assuntos a serem abordados posteriormente, Arruda (2000, p. 165), no trabalho sobre o sertão de São Paulo - "Cidades e Sertões", afirma que:

[...] sertão é uma descrição da natureza, uma paisagem, ou muitas paisagens com o mesmo nome. A utilização do termo é bastante antiga, mas não é uma palavra brasileira. Suas origens remontam ao período medieval português e é encontrado na África. Em Portugal, estaria ligado à região de terras secas, pouco férteis e despovoadas. O que interessa é que ela serviu e serve para designar diversas realidades físicas e assumiu na cultura brasileira, um enorme significado. É também 
SANTOS, J. C. V.; CARNEIRO, V. A.; SILVA, L. G.; DRUCIAKI, V. P.

Paisagens e empirismo, elementos constitutivos das experiências em Geografia: um estudo sobre as veredas do chapadão de Catalão (Goiás)

um dos elementos de organização das representações espaciais da sociedade brasileira.

Com grande importância conceitual na construção deste artigo sobre veredas, Silva e Silva (1998) e Sugionahara (1998 apud OLIVEIRA; MACHADO, 1998) discorrem que a palavra "paisagem" apresenta diferentes sentidos, dependendo da percepção de cada pessoa (experiência de vida, profissão, entre outros fatores). Quando se coloca diante de determinada paisagem, é possível interagir com ela, percebendo-a por sentidos, conhecendo-a pelos pensamentos e modificando-a a partir do fazer.

Nesse contexto, Ferreira (2006, p. 7) enfatiza que “[...] ao analisarmos uma paisagem, temos que considerar uma série de fatores que estão condicionados a percepção da mesma [sic]". Ao utilizar a percepção da paisagem como metodologia de investigação da biodiversidade em áreas de veredas e cerrado, Kates (1970 apud GOODEY; GOLD, 1986, p. 39) assevera que, além de sensibilizar aqueles que gerenciam o ambiente, a proposta leva em consideração os pensamentos daqueles que o usam. Portanto, os estudos das percepções e das atitudes ambientais podem tornar planos e projetos mais efetivos, assegurando sua adequação aos lugares e até fornecendo um veículo para influenciar e estudar a preferência e o gosto do público.

Nessa discussão, Oliveira (1977, p. 61) destaca que “[...] o fenômeno perceptivo não pode ser estudado como um evento isolado, nem pode ser isolável da vida cotidiana das pessoas". É impossível pensar as diversas veredas retirando as relações humanas pretéritas e atuais, em que podem ser percebidas e visualizadas como fonte de vida para os povos cerradeiros. "A percepção deve ser encarada como uma fase da ação exercida pelo sujeito sobre os objetos, pois, as atividades não apresentam como simples justaposições, mas como um encadeamento, em que umas estão ligas as outras" (OLIVEIRA, 1977, p. 61). Goodey e Gold (1986, p. 12) ponderam que:

O termo percepção talvez não tenha sido nunca o mais correto, mas a causa e a abordagem que ele acabou por representar tem um significado central na geografia, e fornece um meio fácil para o intercâmbio com aqueles que foram treinados em outras áreas de estudo e pesquisa.

Enquanto isso, Oliveira (1977) menciona que o espaço é o problema básico de toda percepção, em que o conhecimento do mundo físico é tanto perceptivo como 
SANTOS, J. C. V.; CARNEIRO, V. A.; SILVA, L. G.; DRUCIAKI, V. P.

Paisagens e empirismo, elementos constitutivos das experiências em Geografia: um estudo sobre as veredas do chapadão de Catalão (Goiás)

representativo. Pode-se afirmar que a percepção concerne a uma interpretação com o fim de restituir a realidade objetiva, a partir da atribuição de significado aos objetos percebidos. As atividades perceptivas constituem uma problemática com aspectos referentes a ilusões secundárias, constâncias perceptivas, causalidade perceptiva e percepção dos movimentos e da velocidade.

Antes dos resultados e das percepções in loco no trabalho de campo, é importante trazer o conceito de vereda. Meirelles et al. (2004, p. 43) caracterizam-na como um tipo fisionômico do cerrado que ocorre, geralmente, próximo às nascentes e em solos saturados na maior parte do ano. É um ecossistema de grande relevância, considerado bacia coletora:

[...] das águas absorvidas pelos platôs adjacentes, funcionando como vias de drenagem e contribuindo para a perenidade e a regularidade dos cursos d'água da região. A Vereda é uma comunidade hidrófila, formada por dois estratos: um herbáceo-graminoso contínuo, que ocupa maior parte de sua área; e outro arbustivoarbóreo com predominância de indivíduos da palmeira arbórea Mauritia flexuosa, com cobertura entre $5 \%$ e $10 \%$.

Os estudos de Carvalho (1991) demonstram que as veredas são subsistemas úmidos que participam do controle do fluxo do lençol freático, desempenhando papel fundamental no equilíbrio hidrológico dos cursos fluviais no cerrado. Constitui-se num sistema represador de água em domínio do relevo de chapada, crucial para a perenização dos cursos fluviais, a jusante desses sistemas. Representam também um ambiente de grande relevância dentro do cerrado, por serem responsáveis pela manutenção e multiplicação da fauna terrestre e aquática.

Todavia, as veredas são sensíveis à alteração e apresentam pouca capacidade regenerativa, quando perturbadas. Para Tubelis (2009, p. 363):

[...] veredas são fisionomias com formato linear que ocorrem em solos hidromórficos geralmente ao longo de estreitos cursos d'água. Crescem usualmente em relevo plano ou próximo a nascentes. São marcadas pela abundância de buritis (Mauritia flexuosa), que se destacam sobre outras árvores, arbustos, e um denso estrato herbáceo.

No estudo das áreas úmidas, a matéria morta é decomposta lentamente por anaerobiose, em função do alagamento, o que resulta na substancial acumulação de matéria orgânica na cobertura pedológica. Esses ecossistemas estão fortemente ameaçados em todo o planeta, e grande parte já foi destruída, inclusive, em virtude da drenagem para uso agrícola. 
SANTOS, J. C. V.; CARNEIRO, V. A.; SILVA, L. G.; DRUCIAKI, V. P.

Paisagens e empirismo, elementos constitutivos das experiências em Geografia: um estudo sobre as veredas do chapadão de Catalão (Goiás)

O problema ambiental descrito é perceptível nas paisagens do chapadão, no município de Catalão, no sudeste goiano (Figura 1). Para Ferreira (2006, p. 15):

A ocupação acelerada da região do Planalto Central Brasileiro por projetos agrícolas cada vez mais tecnificado, a construção de barragens nas cabeceiras de drenagem, ambientes das Veredas, têm causado reflexos irreversíveis para a sobrevivência dos mesmos [sic], levando a perda de paisagens importantes para o Bioma Cerrado. A configuração de outros modelos de ambientes de Veredas talvez tenham se perdido nesse processo acelerado de destruição desses ambientes.

Figura 1 - Drenagem em vereda no chapadão de Catalão (GO), paisagem ocupada pela agricultura mecanizada

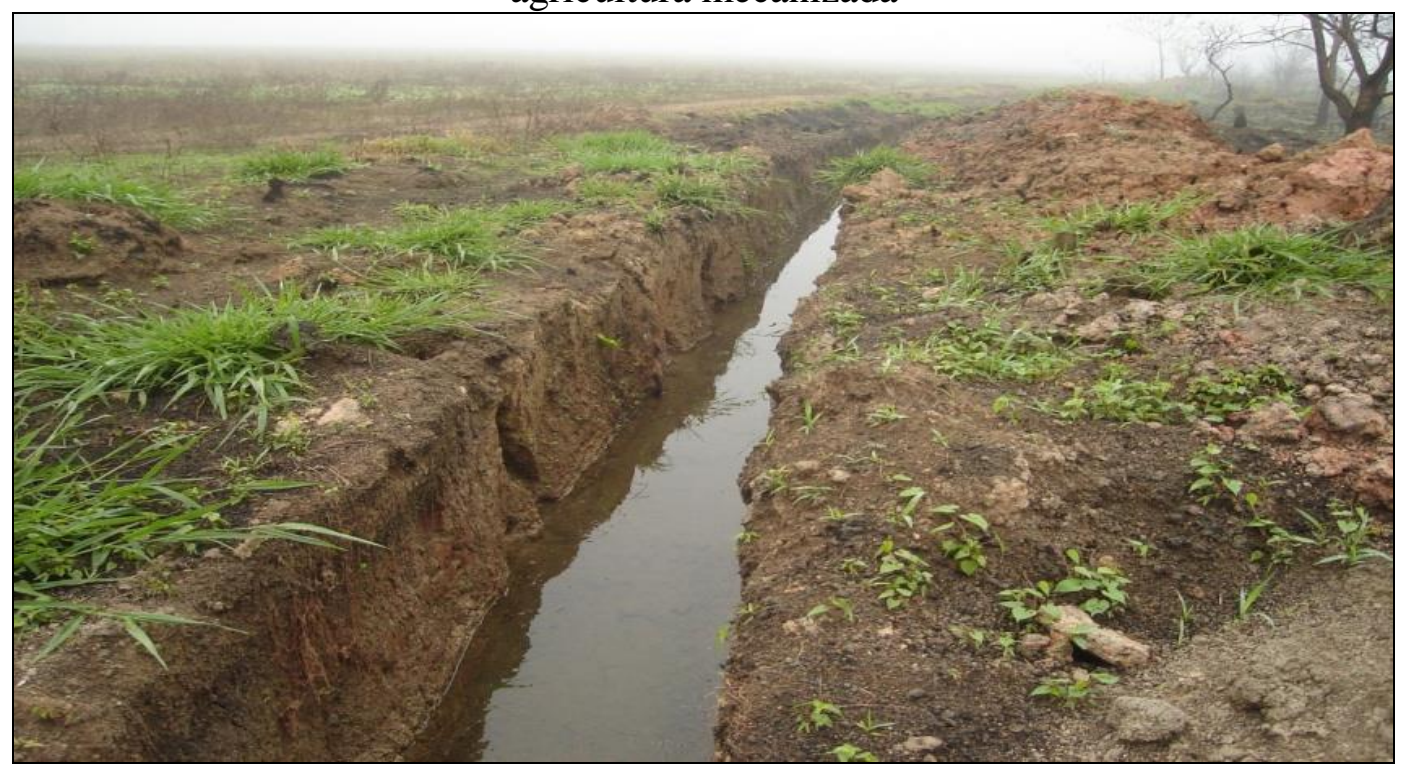

Fonte: Santos, J. C. V. (2015).

A preocupação reside no processo de intervenção do homem nessas paisagens, principalmente com a perda da identidade cultural da região que, irremediavelmente, está sendo aculturada por práticas modernas de desenvolvimento global. Nesse contexto, Meirelles et al. (2004) expõem que as mudanças antrópicas ocasionam às paisagens úmidas do cerrado a perda da biodiversidade e a desestruturação de tais ecossistemas, com consequências sérias para as drenagens no local.

As comunidades herbáceas de áreas úmidas do cerrado estão fortemente ameaçadas tanto por perturbações locais (drenagem, pastoreio, desmatamento) quanto por mudanças no uso da cobertura pedológica da bacia hidrográfica onde se encontram, o que leva à redução na profundidade do lençol freático. Logo, além da preservação dessas áreas, são imprescindíveis a conservação e a manutenção do regime hídrico da bacia hidrográfica que 
SANTOS, J. C. V.; CARNEIRO, V. A.; SILVA, L. G.; DRUCIAKI, V. P.

Paisagens e empirismo, elementos constitutivos das experiências em Geografia: um estudo sobre as veredas do chapadão de Catalão (Goiás)

insere áreas úmidas para garantir a efetiva preservação e gestão racional e sistêmica, conforme as pesquisas realizadas por Meirelles et al. (2004). No prisma internacional:

O termo área úmida ou zona úmida designa espaços terrestres onde se observa o encharcamento sazonal ou permanente do solo. A saturação por água determina o desenvolvimento do solo e das formas de vida dessas áreas que, no Brasil, são conhecidas como brejos, brejões, pântanos, pantanais, varjões, charcos, [veredas], alagados e banhados, entre outros (MARIA, 2009, p. 3).

Guerra (1978, p. 63) caracteriza as áreas úmidas como brejos: “[...] terreno plano, encharcado, que aparece nas regiões de cabeceira ou em zonas de transbordamento de rios". Por essa definição, pode-se pensar que as veredas possuem um aspecto brejoso, mas nem todo brejo é uma vereda, ou seja, as áreas de alagamentos de rios como Araguaia, Amazonas, São Francisco e outras não são paisagens de veredas. Em "Modelos geomorfológicos das veredas em ambiente de cerrado", Ferreira (2006, p. 7) as define como:

[...] importante subsistema do Bioma Cerrado, possuindo, além do significado ecológico, um papel socioeconômico e estético-paisagístico que lhe confere importância regional, principalmente quanto ao aspecto de constituírem refúgios fauno-florísticos, onde várias espécies da fauna e da flora são encontradas e dependem desse ambiente para sua sobrevivência. Além disso, constituem ambientes de nascedouros das fontes hídricas do Planalto Central Brasileiro, que alimentam cursos d'água que formam a rede hídrica local e regional, bem como formam as três principais bacias hidrográficas do Brasil, além de serem utilizadas para projetos de irrigação e dessedentação de animais.

O mesmo autor afirma que as veredas são como "[...] um sistema de drenagem superficial, geralmente mal delimitado, regulado pelo regime climático regional, composta por uma trama fina e mal definida de caminhos d'água intermitentes" (2006, p. 7). Para Meirelles et al. (2004, p. 41), “[...] essas paisagens úmidas ocupam apenas $2 \%$ do planeta Terra, estima-se que contenham de $10 \%$ a 14\% do carbono orgânico existente".

Conforme a Lei n. 12.651, de 25 de maio de 2012, que dispõe sobre a proteção da vegetação nativa, em seu Art. $3^{\circ}$, item XII, a vereda possui caráter fitofisionômico, pois se tratada de uma fitofisionomia de savana, encontrada em solos hidromórficos, usualmente com a palmeira arbórea Mauritia flexuosa, em que o buriti é emergente e não forma dossel, em meio a agrupamentos de espécies arbustivo-herbáceas (BRASIL, 2012).

Para entender e prever as mudanças ambientais nas APPs, ou seja, nos ambientes de veredas, é preciso reconhecer a natureza das ligações entre os componentes de uma paisagem, verificando se ela é capaz de resistir ou absorver impulsos de mudanças e a 
SANTOS, J. C. V.; CARNEIRO, V. A.; SILVA, L. G.; DRUCIAKI, V. P.

Paisagens e empirismo, elementos constitutivos das experiências em Geografia: um estudo sobre as veredas do chapadão de Catalão (Goiás)

interação entre os processos, a fim de induzir tais modificações (ALLISON; THOMAS, 1993; CRUZ, 1998). Na sequência deste artigo serão apresentados os resultados do trabalho de campo nas paisagens de veredas e as percepções dos investigadores que se fizeram presentes nos trabalhos de campo.

\section{RESULTADOS E DISCUSSÕES - TRABALHO DE CAMPO NAS VEREDAS URBANAS E RURAIS}

Antes de apresentar os resultados do campo, é essencial uma abordagem sobre a importância do trabalho de campo. Na Geografia, as incursões não são resumidas apenas aos interesses específicos, como também apresentam contribuições para o entendimento das relações socioespaciais e, com isso, uma melhor forma de uso do solo, do meio ambiente e de diversos recursos, a exemplo da compreensão da dinâmica e das fitofisionomias das veredas.

Nas palavras de Castrogiovanni (2000, p. 13), o trabalho de campo concerne a "[...] toda atividade oportunizada fora da sala de aula que busque concretizar etapas do conhecimento e/ou desenvolver habilidades em situações concretas perante a observação e participação". Pontua-se também que:

[...] o trabalho de campo é benéfico e cumpre seus objetivos científicos e pedagógicos. Portanto, dizemos que ele foi utilizado para vários fins pelos povos, correntes científicas e escolas geográficas; e, cabe ao geógrafo entoar a significância dessa atividade, onde o campo é um laboratório (CARNEIRO, 2009, p. 105).

É importante lembrar que o trabalho de campo ou visita técnica ${ }^{3}$ é um procedimento de investigação que permite a leitura direta e enriquecedora dos lugares estudados. Paralelamente ao desenvolvimento de atitudes, a escrita de tal documento enfrenta decisões práticas para ser realizada de fato. A vivência em campo é uma ferramenta útil para os educadores, e Santos (1999) diz que o trabalho de campo não se limita apenas a ouvir as pessoas, pontuando-se o sentido que elas dão às coisas, ao terminado.

O empírico visa promover contato, ou seja, é a análise voltada às tendências de interpretações que os pesquisados promovem do mundo, num movimento dinâmico orientado por determinações sociais do lugar. Esse contato com o vivido pode ser registrado no caderno

\footnotetext{
${ }^{3}$ Alguns autores discutem o conceito de visita técnica. Nesse sentido, recomenda-se a leitura de Veloso (2000). 
SANTOS, J. C. V.; CARNEIRO, V. A.; SILVA, L. G.; DRUCIAKI, V. P.

Paisagens e empirismo, elementos constitutivos das experiências em Geografia: um estudo sobre as veredas do chapadão de Catalão (Goiás)

ou diário de campo que, para Lopes (2002, p. 135), requer um esforço, sem se tratar apenas de escrever uma série de dados num caderno:

Trata-se de registrar o convívio com os nossos informantes, convívio este que não está representado apenas pela fala dos mesmos [sic], no registro que fazemos do próprio espaço. O diário de campo ajuda-nos a reconstruir a história dos indivíduos em diversos aspectos.

A produção do diário de campo é a relação íntima do pesquisador com a paisagem estudada, relatando no papel as emoções, as memórias e os pertencimentos do lugar. $\mathrm{O}$ trabalho de campo, independentemente da paisagem a ser visitada, merece uma reflexão dos aspectos observados e dos novos conceitos formados. Portanto, nesta parte serão apresentadas as observações empíricas da atividade de campo realizadas nos trechos A (Catalão-Goiandira) e B (Catalão-Ipameri), na microrregião de Catalão, no sudeste goiano (Figura 2).

$\mathrm{Na}$ primeira parada no campo foram feitas observações sobre covoais, campo limpo com murundu, campo limpo seco, campo úmido e vereda. Na conceituação de Guerra (1978, p. 300), murundus é um:

Termo usado no Pantanal Mato-Grossense para pequenas elevações circulares, com mais ou menos um metro de altura, por quatro a seis metros de diâmetro, tratando-se possivelmente, de dunas incipientes. Os murundus situam-se na periferia das baías ou nas encostas das cordilheiras. O termo murundu é usado em várias partes do Brasil, como nos estados do Rio Grande do Sul, Bahia e Ceará, com o sentido de montículo. Na Chapada Diamantina, no Estado da Bahia, alguns caboclos denominam os montículos dos cupins como murundus.

Cabe inferir que os campos de murundus são áreas úmidas caracterizadas pela presença de inúmeros montes arredondados de terra, formando microrrelevos com vegetação arbórea, circundados por uma área plana onde se desenvolvem gramíneas (OLIVEIRA FILHO; FURLEY, 1990; OLIVEIRA FILHO, 1992). Por sua vez, os covoais são áreas úmidas, ou seja, APPs que são manejadas e até drenadas de maneira ilegal. É alertado também que as APPs do planalto brasileiro, denominadas localmente como covoais, "[...] são ambientes únicos no planeta, apresentam fauna e flora desconhecidas e já ameaçadas, em consequência da ocupação descontrolada e indevida desses habitats" (UFG, s.d.) ${ }^{4}$.

\footnotetext{
${ }^{4}$ Fragmento textual capturado em site da UFG - Regional Jataí.
} 
SANTOS, J. C. V.; CARNEIRO, V. A.; SILVA, L. G.; DRUCIAKI, V. P.

Paisagens e empirismo, elementos constitutivos das experiências em Geografia: um estudo sobre as veredas do chapadão de Catalão (Goiás)

Figura 2 - Trechos visitados na microrregião de Catalão

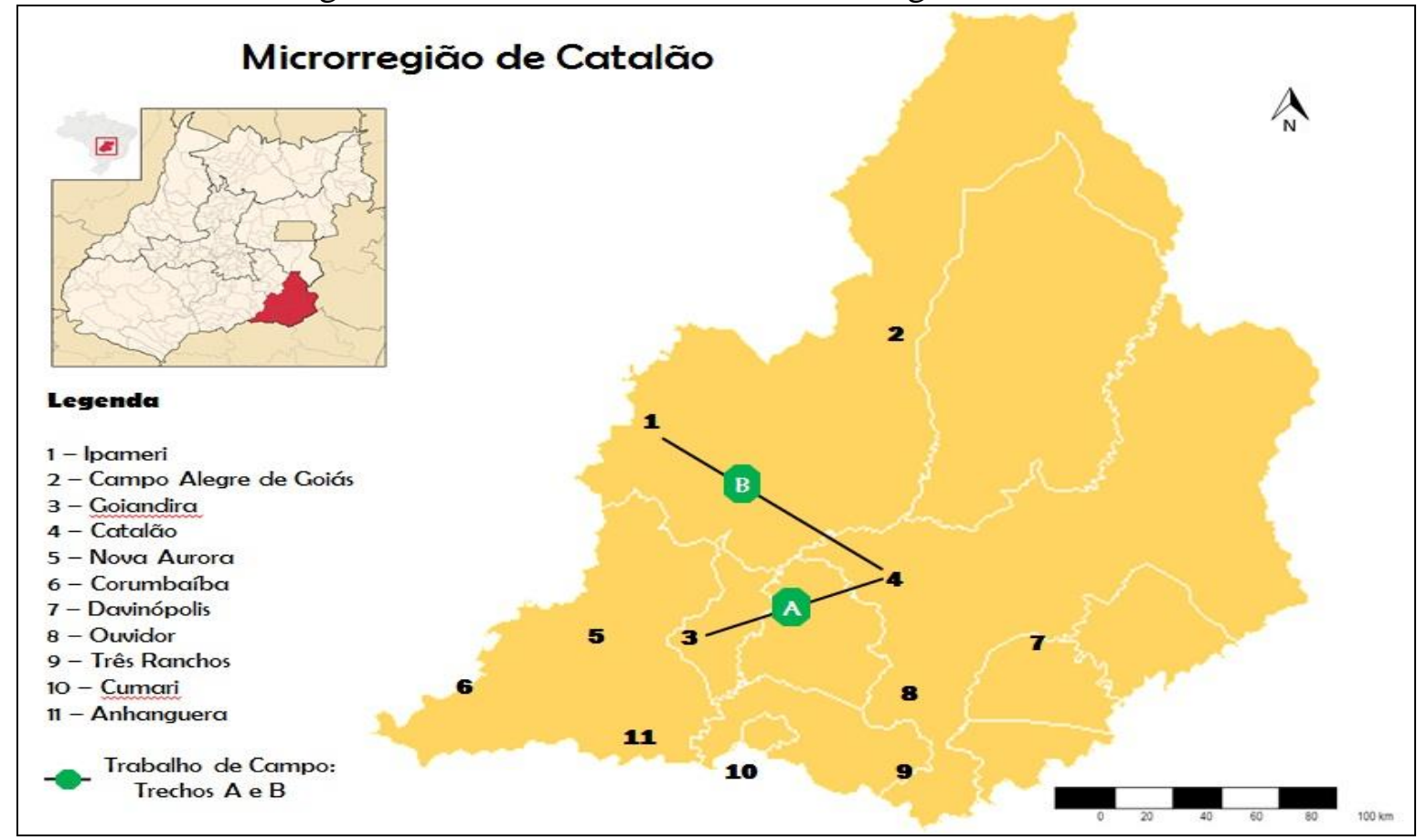

Fonte: Wikipédia (s.d.), com organização de Carneiro (2017).

Cabe abordar que o campo limpo ou sujo apresenta variações dependentes de "[...] particularidades ambientais, determinadas pela umidade do solo e topografia. Na presença de um reservatório subterrâneo de água profundo ocorre o Campo Limpo Seco" (RIBEIRO; WALTER, s.d.) - tal caso é verificado na área do chapadão de Catalão. Também na área visitada se constatou a presença do campo limpo úmido, onde o lençol freático é alto e goteja ${ }^{5}$ na superfície do terreno. Com relação ao subsistema de veredas e de ambientes alagadiços, Barbosa e Magalhães (2011, p. 12) pontuam que:

As cabeceiras de alguns córregos e rios são, às vezes, caracterizados por ambientes alagadiços, decorrentes do afloramento do lençol de água ou ainda em virtude de características impermeabilizantes do solo. Nesse local, são muito frequentes as veredas, que são paisagens nas quais predominam os coqueiros buriti e buritirana que, geralmente, distribuem-se acompanhando os cursos d'água até a parte média de alguns rios, formando uma paisagem muito bonita.

De acordo com o professor responsável ${ }^{6}$ pelo trabalho de campo, 50 metros em torno das paisagens são considerados APPs. Nesses espaços, a matéria orgânica é ácida, e o húmus é a parte mineralizada dessa rica camada; quando ocorre a queima, resta apenas a

\footnotetext{
${ }^{5}$ Surgência d'água.

${ }^{6}$ Prof. Dr. Idelvone Mendes Ferreira, da Universidade Federal de Goiás (UFG) - Regional Catalão.
} 
SANTOS, J. C. V.; CARNEIRO, V. A.; SILVA, L. G.; DRUCIAKI, V. P.

Paisagens e empirismo, elementos constitutivos das experiências em Geografia: um estudo sobre as veredas do chapadão de Catalão (Goiás)

argila. Perceberam-se a raiz de um buriti, cuja respiração é aérea; o fruto da árvore, utilizado para doce e artesanato; e a folha, usada na queima de suínos ${ }^{7}$.

Nesse ponto (Figura 3), o buriti não é muito grande, pois não existe disputa por luminosidade, e a paisagem foi caracterizada como de anfiteatros pantanosos, ou seja, cabeceiras de drenagem em dales, pontilhados por buritis (AB'SÁBER, 2003). Na segunda parada se visualizou uma palmácea não arbustiva, indicativo de $\mathrm{pH}$ baixo e que tem um palmito doce. Curi (1993, p. 64) define o pH do solo como:

[...] logaritmo do inverso da atividade do íon hidrogênico de um solo. Na determinação do grau de acidez (ou alcalinidade) de um solo, por meio de um eletrodo especificado, o grau de umidade da amostra é expresso através da relação solo-água.

Figura 3 - Primeira parada na vereda do chapadão de Catalão

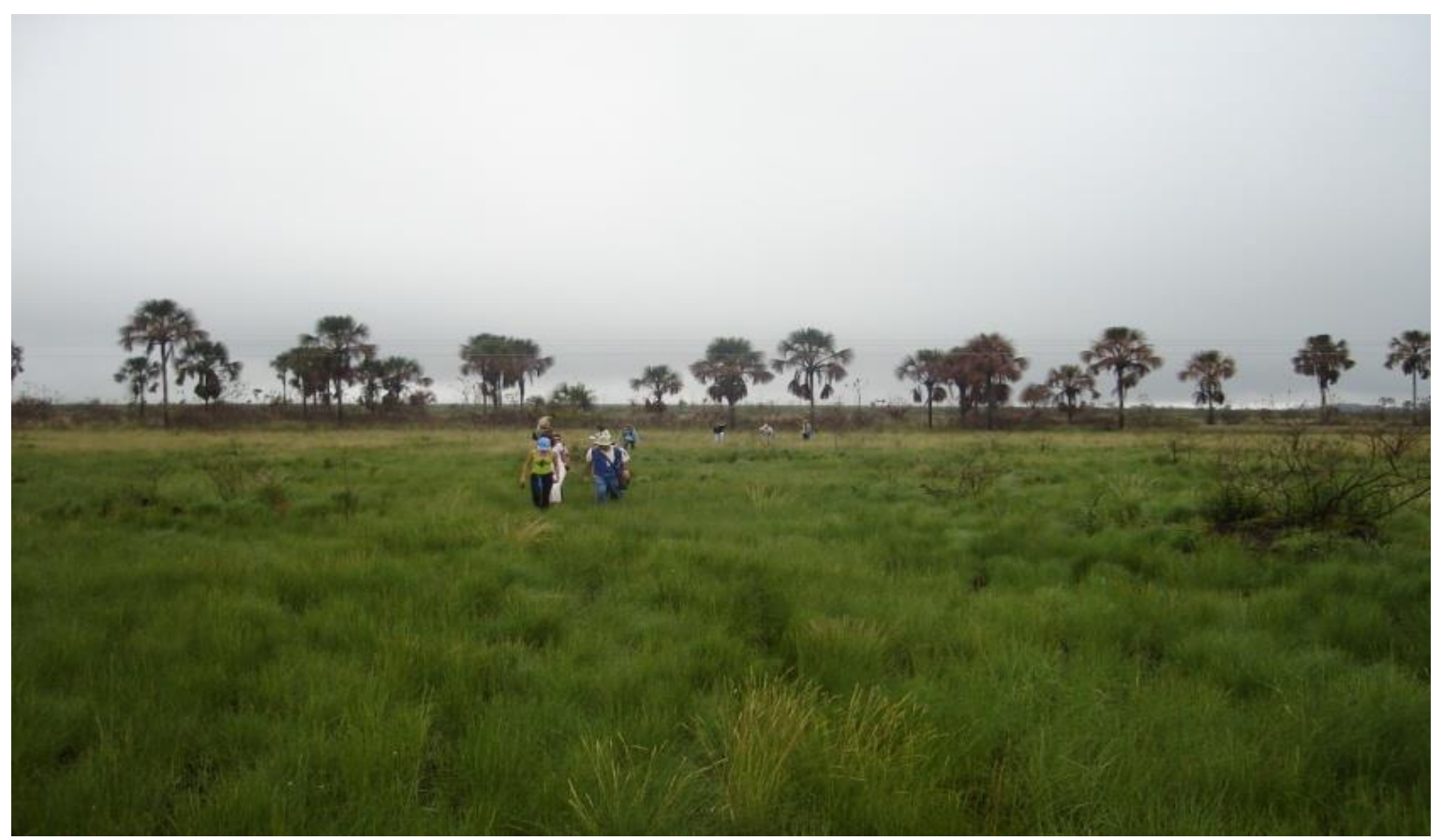

Fonte: Santos, J. C. V. (2015).

A terceira parada, ou seja, a segunda vereda, foi referenciada pela presença das pequenas lagoas descritas por João Guimarães Rosa (1956), em “Grande Sertão: Veredas”. Ela tem a forma de anfiteatro, e outra parte foi caracterizada como de sopé, encaixada e com

\footnotetext{
${ }^{7}$ O porco era "sapecado", ou seja, queimado na palha de bananeira, milho, restos de capim seco e folhas de buriti para depois começar o retalhamento das carnes e a retirada de banha, toucinho e outras partes para consumo.
} 
SANTOS, J. C. V.; CARNEIRO, V. A.; SILVA, L. G.; DRUCIAKI, V. P.

Paisagens e empirismo, elementos constitutivos das experiências em Geografia: um estudo sobre as veredas do chapadão de Catalão (Goiás)

vegetação no meio, sendo chamada de vereda mista; na parte mais baixa do relevo, forma-se um cordão linear.

Para Ferreira (2006, p. 10), as veredas de sopé “[...] se desenvolvem no sopé de escarpa - originadas do extravasamento de lençóis profundos", e as de cordão linear "[...] se desenvolvem nas margens de cursos d'água de médio porte, formando cordões lineares com vegetação ciliar em áreas sedimentares”. Na vereda da Fazenda Eldorado, na quarta parada, notou-se o afloramento do lençol d'água, com presença de ferro lavado e de uma película oleosa (tipo filme plástico transparente) na superfície do espelho d’água.

A vereda de encaixe, na quinta parada, não possui fase de transição e foi definida como vereda mista, com material silto/arenoso, em que os níveis de sedimentação são diferenciados e com um colúvio em cima, pertencente ao grupo Araxá. Uma das características dessa paisagem era a área inundável sedimentada em virtude da construção da rodovia; com isso, havia menos matéria orgânica, e o espaço ripário era bastante largo. $\mathrm{O}$ professor responsável pelo trabalho de campo indicou grande presença de sílica $\left(\mathrm{SiO}_{2}\right)$ no tronco da palmeira buriti (Mauritia flexuosa), além do período de floração. Para Guerra (1978, p. 393), a sílica ou óxido de silício é uma:

Substância poliforma que se apresenta na natureza em vários estados: amorfa e hidratada (sílica gelatinosa e opala); cristalizada e anidra (quartzo, tridimita, cristobalita e caldedônia); a sílica é um composto extremamente estável na natureza; somente o ácido fluorídrico é capaz de decompô-la a frio; entra na formação de grande número de minerais podendo-se dizer que é o eixo de todo reino mineral.

A sexta parada ocorreu no espaço urbano de Catalão (GO), numa vereda contínua que foi urbanizada e transformada em área de lazer, com brinquedos e espaços para caminhadas, atraindo novos comércios para atender o público local. O lago trouxe uma nova percepção imagética para a cidade e valorizou a área urbana, o que foi pensado com base no plano diretor, mas provocando a morte da vereda.

Na sétima parada ou ponto de estudo, na região do Córrego do Almoço, bairro dos Buritis, cidade de Catalão (GO), foi visualizada uma vereda linear impactada com lixo, esgoto e plantas invasoras, sem preservação dos 50 metros da APP e com a área ripária seriamente condenada. As observações no campo são comprovadas nas palavras de Meirelles et al. (2004, p. 64): 
SANTOS, J. C. V.; CARNEIRO, V. A.; SILVA, L. G.; DRUCIAKI, V. P.

Paisagens e empirismo, elementos constitutivos das experiências em Geografia: um estudo sobre as veredas do chapadão de Catalão (Goiás)

Perturbações na flora local de Áreas Úmidas do Cerrado, em consequência da antropização, podem ser evidenciadas pelas mudanças florísticas e fitossociológicas das áreas alteradas, quando comparadas com áreas similares preservadas. Além disso, o rebaixamento do lençol freático em Áreas Úmidas de Cerrado parece determinar que espécies arbóreo-arbustivas nativas tornem-se eficientes colonizadoras dessas áreas [...].

Na rodovia BR-050 (oitava parada), observaram-se uma vereda com vegetação bem densa e uma transição abrupta direta do cerradão para a vereda, além da samambaiaçu (Dicksonia sellowiana); por conseguinte, a área foi definida como uma paisagem mista. No município de Goiandira (GO) houve a nona parada (Figura 4), onde se notaram vários pontos de vereda. No primeiro momento se destacaram o campo limpo e uma voçoroca em paisagens de estruturas de gnaisses intemperizados, sendo classificada como vereda de terraço com fundo chato, sedimentada por coluvionamento.

Figura 4 - Vereda no município de Goiandira (GO)

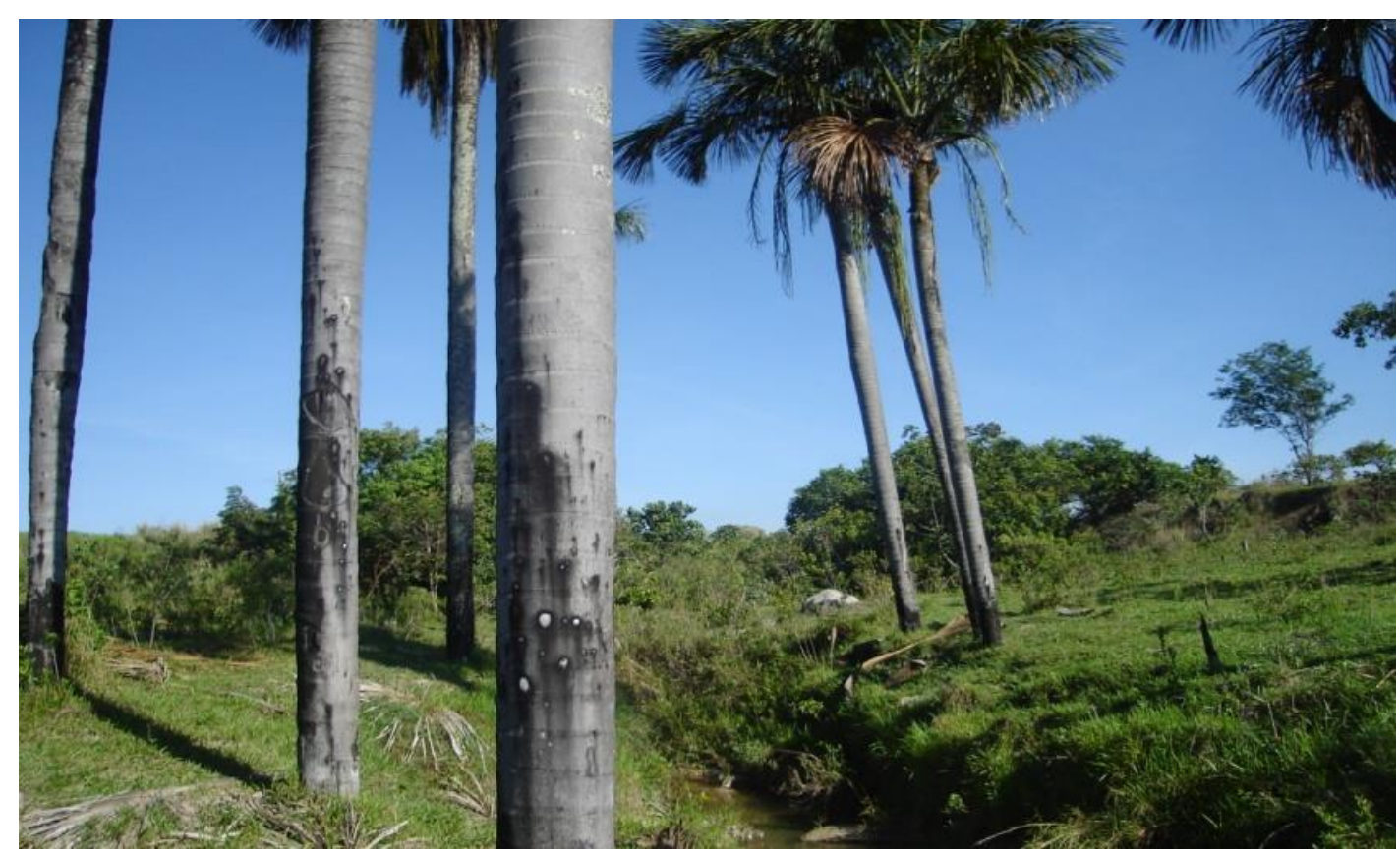

Fonte: Santos, J. C. V. (2015).

De acordo com Ferreira (2006, p. 10), as veredas de terraços se “[...] desenvolvem nas depressões, que se subdividem em Veredas de Superfície Aplainada e de Terraço Fluvial - desenvolvem em áreas aplainadas com origem por extravasamento de lençóis d'água subsuperficiais". Para Guerra (1978, p. 100), o colúvio que sedimentou a vereda é um: 
SANTOS, J. C. V.; CARNEIRO, V. A.; SILVA, L. G.; DRUCIAKI, V. P.

Paisagens e empirismo, elementos constitutivos das experiências em Geografia: um estudo sobre as veredas do chapadão de Catalão (Goiás)

\begin{abstract}
Material transportado de um local para outro, principalmente por efeito de gravidade. O material coluvial só aparece no sopé das vertentes ou em lugares pouco afastados de declives que lhe estão acima. No material detrítico, pouco grosseiro, de uma encosta, nem sempre é fácil separarmos a interferência do material de colúvio, do residual ou ainda do aluvial. Às vezes, há maior predominância de um deles, que mascara completamente os outros.
\end{abstract}

Nessa vereda, os sedimentos arenoargilosos, com mais areia do que argila, são confirmados pela presença de sílica $\left(\mathrm{SiO}_{2}\right)$. Marginalmente à nona paisagem, notaram-se uma ferrovia e o entorno utilizado pela pecuária. Em outro ponto da parada, a vereda linear contém taboas (Typha domingensis) e juncos (Juncus effusus), com lençol freático aflorante e zona alagadiça que condiciona a formação de tais elementos. As aves (papagaios, mulatas, maritacas, periquitos e passarinhos) usam os ambientes freatófitos para pouso, descanso, alimentação e dessedentação. A drenagem com margens erodidas foi um dos impactos percebidos pelo mau uso da paisagem.

Conforme os estudos realizados por Martins (2010) e Carvalho (2015), as veredas, além de corresponderem a represas naturais responsáveis por manter a perenização dos cursos fluviais que estão à jusante desses sistemas, se constituem em corredores ecológicos naturais. A preservação de tais áreas contribui para a circulação de animais entre os remanescentes florestais; o fornecimento de alimento e refúgio para diversas espécies da fauna; a melhoria dos aspectos paisagísticos; e o resguardo e exemplares da flora do cerrado, muitas vezes endêmicos.

Na décima parada (rodovia GO-213), entre os municípios de Ipameri e Caldas Novas (GO), constatou-se a vereda de terraço, formada por sedimentação e solo pedregoso nas bordas há o cerrado rupestre e, ao fundo, tanto a vereda mista quanto a mata de galeria. Nessa paisagem, a rodovia estadual secciona o ambiente das veredas, provocando um desequilíbrio na dinâmica biogeográfica.

A vereda de enclave é observada na $11^{\mathrm{a}}$ parada no campo, entre vertentes, sem transição - área ripária, nascendo na linha de sedimento, com presença do óxido de ferro. Conforme Ferreira (2006, p. 10), essas paisagens “[...] se desenvolvem na forma de enclave entre duas elevações no terreno em áreas movimentadas, originadas pelo afloramento/extravasamento dos lençóis profundos”. Steinke (2007, p. 56) assegura que as: 
SANTOS, J. C. V.; CARNEIRO, V. A.; SILVA, L. G.; DRUCIAKI, V. P.

Paisagens e empirismo, elementos constitutivos das experiências em Geografia: um estudo sobre as veredas do chapadão de Catalão (Goiás)

[...] áreas úmidas são zonas resultantes de dois fatores correlacionados, a geomorfologia e os recursos hídricos de um determinado ambiente. O relevo apresenta características que favorecem o acúmulo de água que, por sua vez, controla a vida animal e vegetal deste ambiente.

E na última parada $\left(12^{\mathrm{a}}\right)$, na região da Fazenda Lageado, verifica-se uma vereda de vale assimétrico, isto é, com assimetria de relevo, mas sem sedimentação, fugindo das concepções do relevo da chapada, com solo rochoso, vegetação mista e sem curso d'água. Nesse ambiente, deparou-se com o capim-colchão de pombo (Digitaria horizontalis Willd.), pindaíbas (Xylopia emarginata Mart.) e jaborandis-do-mato (Piper aduncum L.). “As Veredas que se desenvolvem em vales assimétricos, resultantes do afloramento do lençol d'água em áreas de contato litológico, responsável pela assimetria das vertentes" (FERREIRA, 2006, p. 10). Convém mencionar que outros conceitos de veredas foram trabalhados por Ferreira (2006, p. 10), a saber:

\begin{abstract}
Vereda de Superfície Tabular: que se desenvolvem em áreas de planaltos, originadas do extravasamento de lençóis aquíferos superficiais. Geralmente são veredas mais antigas. Veredas de Encosta: em geral são restos de antigas Veredas de Superfície Tabular e são, por conseguinte, mais jovens que essas, em áreas de desnível topográfico com afloramento do aquífero superficial. Veredas de Patamar: Veredas que se desenvolvem em Patamar - originadas do extravasamento de mais de um lençol d'água.
\end{abstract}

Nas bacias hidrográficas do bioma cerrado existe uma hierarquia na rede potâmica, em que a água escoa das chapadas ou chapadões para os fundos de vales. Portanto, os estudos desenvolvidos em sala de aula e no trabalho de campo mostraram o papel relevante das veredas na manutenção desse sistema, para que o cerrado possa continuar sendo visto como a "caixa d'água" e/ou o "berço das águas" do planalto central, onde principiam as principais bacias brasileiras (Paraná/Paraguai, São Francisco, Araguaia-Tocantins, Parnaíba e Amazônica) que têm nascentes nos pontos mais elevados dessa paisagem.

Esse ambiente potâmico também abriga os aquíferos Guarani, Bambuí e Urucuia. Conforme Barbosa e Magalhães (2011, p. 14):

Esses aquíferos vêm se formando durante milhões de anos, de pouco tempo para cá não estão sendo recarregados como deveriam, para sustentar os mananciais. Isso ocorre porque a recarga dos aquíferos se dá pelas suas bordas nas áreas planas, onde a água pluvial infiltra e é absorvida cerca de $70 \%$ pelo sistema radicular da vegetação nativa, alimentando num primeiro momento o lençol freático e lentamente vai abastecendo e se armazenando nos lençóis mais subterrâneos. 
SANTOS, J. C. V.; CARNEIRO, V. A.; SILVA, L. G.; DRUCIAKI, V. P.

Paisagens e empirismo, elementos constitutivos das experiências em Geografia: um estudo sobre as veredas do chapadão de Catalão (Goiás)

Perceber as alterações na dinâmica do subsistema de veredas é um passo importante para uma gestão eficiente dessas áreas.

\section{CONSIDERAÇÕES FINAIS}

O trabalho de campo e a parte teórica foram fundamentais para compreender as veredas como parte das riquezas do cerrado e um mosaico natural desse ecossistema. $\mathrm{Na}$ região estudada, notou-se que a diversidade paisagística está ameaçada pelo chamado "desenvolvimento" econômico, especificamente pelo agronegócio.

Como a atividade de campo foi desenvolvida ao final do mês de novembro, as paisagens visitadas estavam menos secas, em função do início do período chuvoso, apesar de os ambientes pontuais deste estudo permanecerem com umidade durante todo o ano, independentemente das estações de inverno seco ou de verão chuvoso. Não foi possível verificar um grande número de animais, e sim algumas espécies, como cobras e pequenos seres aquáticos.

Não foi possível registrar a diversidade de mamíferos, aves e répteis, mas, com relação à flora, o buriti se destaca na paisagem onde, de acordo com as explicações no campo, ele foi utilizado principalmente pelas comunidades pretéritas do cerrado, fornecendo alimentos, bebidas e materiais para as moradias. Na atualidade, as veredas têm como função fornecer água para as grandes empresas agrícolas, em que a vegetação identitária é afogada por reservatórios criados nessas paisagens.

As ações antrópicas capitalizadas têm sido uma ameaça para preservação e manutenção desses ambientes úmidos. Entre os pontos visitados as marcas mais degradantes estão na região do chapadão de Catalão e no espaço urbano (sede do município). Nos momentos de abordagens em campo, não foi citado nenhuma ação e nem projetos de preservação e conservação da biodiversidade das Veredas nos municípios visitados (Catalão, Goiandira e Ipameri). Portanto, é fundamental que medidas na forma de gestão dos territórios com alto nível de fragilidade ambiental sejam tomadas para minimizar as formas de agressão praticadas pelos homens detentores do capital na região.

A suscetibilidade das veredas visitadas tem sido descaracterizada por construções de ferrovias e rodovias, além do pisoteio do gado que provoca a compactação da 
SANTOS, J. C. V.; CARNEIRO, V. A.; SILVA, L. G.; DRUCIAKI, V. P.

Paisagens e empirismo, elementos constitutivos das experiências em Geografia: um estudo sobre as veredas do chapadão de Catalão (Goiás)

cobertura pedológica e instalação de processos erosivos. Outras perturbações fotografadas e percebidas dizem respeito à drenagem e à queimada na vereda localizada no chapadão de Catalão, o que possivelmente provoca sérias mudanças hídricas no local e se torna uma ameaça para a biodiversidade - as cinzas, nesse caso, substituem os aspectos florísticos. Tais lugares sofrem (e já sofreram) grandes impactos, pois eles também foram desmatados e, com isso, vêm perdendo áreas significativas.

Apesar de o professor responsável pelo trabalho de campo possuir amplo conhecimento científico acerca da temática estudada, considera-se que o desenvolvimento de pesquisas sobre veredas ainda são incipientes. Pensa-se que há poucos grupos de estudos interessados nesse enfoque, e a falta de pesquisa pode levá-las para o afogamento e até mesmo a uma nova "configuração paisagística", perdendo características e identidade.

Assim sendo, é fundamental registrar que este trabalho de campo foi importante para o contato com as veredas e, por meio dele, vivenciar diversidades, perturbações, valores, identidades e mudanças provocadas pela ação antrópica. Nesse entremeio foram relevantes a caderneta de anotações e a máquina fotográfica, instrumentos que viabilizaram a construção do material final.

Destarte, o trabalho de campo, visita técnica ou incursão ao campo auxilia o estudante na compreensão da realidade a partir dos contatos formais e informais, mas isso não esgota a discussão acerca das paisagens visitadas. Processar tais atividades é levar os participantes a um olhar mais aprofundado do lugar e, assim, descrever fatos, acontecimentos e o vivido, sem perder as contradições produzidas nas regiões visitadas.

\section{REFERÊNCIAS}

AB'SÁBER, A. N. Formas de relevo. São Paulo: EDART, 1982.

AB'SÁBER, A. N. Os domínios de natureza do Brasil: potencialidades paisagísticas. São Paulo: Ateliê, 2003.

AB'SÁBER, A. N. Um conceito de geomorfologia a serviço das pesquisas sobre o quaternário. Geomorfologia, São Paulo, n. 18, n.p., 1969.

AGUIAR, L. M. S.; MACHADO, R. B.; MARINHO FILHO, J. A diversidade biológica do cerrado. In: AGUIAR, L. M. S.; CAMARGO, A. J. A. Cerrado: ecologia e caracterização. Planaltina: Embrapa Cerrados; Brasília: Embrapa Informação Tecnológica, 2004, p. 19-42. 
SANTOS, J. C. V.; CARNEIRO, V. A.; SILVA, L. G.; DRUCIAKI, V. P.

Paisagens e empirismo, elementos constitutivos das experiências em Geografia: um estudo sobre as veredas do chapadão de Catalão (Goiás)

ALLISON, R. J.; THOMAS, D. S. G. Landscape sensitivity. New York: John Wiley \& Sons, 1993.

ARAÚJO, A. D.; FREITAS, M. de O.; BAGGIO FILHO, H. Qualidade ambiental da água superficial do córrego Quatro Vinténs no município de Diamantina-MG. Cerrados, Montes Claros, v. 14, n. 1, p. 77-95, jan./jun. 2016.

ARRUDA, G. Cidades e sertões: entre a história e a memória. Bauru: EDUSC, 2000.

BARBOSA, A. S.; MAGALHÃES, T. Cerrado: "dor fantasma” da biodiversidade brasileira. Revista do Instituto Humanitas Unisinos, São Leopoldo, n. 382, p. 11-15, 2011.

BERNALDEZ, F. G. Ecologia y paisaje. Madrid: H. Blume, 1981.

BERTRAND, G. Paisagem e geografia física global - esboço metodológico. Cadernos de Ciências da Terra, São Paulo, n. 13, p. 1-27, 1968.

BOLÓS, M. C. Problemática actual de los estudios de paisaje integrado. Revista de Geografia, Barcelona, v. 15, n. 1-2, p. 45-68, 1981.

BRASIL. Lei n. 12.651, de 25 de maio de 2012. Dispõe sobre a proteção da vegetação nativa; altera as Leis n. 6.938, de 31 de agosto de 1981, 9.393, de 19 de dezembro de 1996, e 11.428, de 22 de dezembro de 2006; revoga as Leis n. 4.771, de 15 de setembro de 1965, e 7.754, de 14 de abril de 1989, e a Medida Provisória n. 2.166-67, de 24 de agosto de 2001; e dá outras providências. Diário Oficial da União, Brasília, 28 maio 2012. Disponível em:

<http://www.planalto.gov.br/ccivil_03/_ato2011-2014/2012/lei/112651.htm>. Acesso em: 20 abr. 2018.

CARNEIRO, V. A. Concepções de trabalho de campo e ensino de Geografia nas licenciaturas do Sudeste Goiano. 2009. 272f. Dissertação (Mestrado) - Universidade Federal de Goiás, Goiânia, 2009.

CARVALHO, A. C. A. Análise ambiental de um subsistema de vereda em unidades de conservação: Reserva Ecológica do IBGE - RECOR e Estação Ecológica de Águas Emendadas - ESECAE/DF. 2015. 127f. Dissertação (Mestrado) - Universidade de Brasília, Brasília, 2015.

CARVALHO, P. G. S. As veredas e sua importância no domínio dos cerrados. Informe Agropecuário, Belo Horizonte, v. 15, n. 168, p. 54-56, 1991.

CASTROGIOVANNI, A. Ensino de geografia: práticas e textualizações no cotidiano. Porto Alegre: Mediação, 2000.

CHRISTOFOLETTI, A. A inserção da geografia física na política de desenvolvimento sustentável. Geografia, Rio Claro, n. 18, p. 1-22, 1993.

COLL, C.; TEBEROSKY, A. História e Geografia. São Paulo: Ática, 2000. 
SANTOS, J. C. V.; CARNEIRO, V. A.; SILVA, L. G.; DRUCIAKI, V. P.

Paisagens e empirismo, elementos constitutivos das experiências em Geografia: um estudo sobre as veredas do chapadão de Catalão (Goiás)

CRUZ, O. A ilha de Santa Catarina e o continente próximo: um estudo de geomorfologia costeira. Florianópolis: EdUFSC, 1998.

CURI, N. Vocabulário de ciência do solo. Campinas: Sociedade Brasileira de Ciência do Solo, 1993.

DEMO, P. Pesquisa qualitativa: busca de equilíbrio entre forma e conteúdo. Revista LatinoAmericana, Ribeirão Preto, v. 6, n. 2, p. 89-104, abr. 1998.

FELTRAN FILHO, A. A estruturação das paisagens nas chapadas do Oeste Mineiro. 1997. 252f. Tese (Doutorado) - Universidade de São Paulo, São Paulo, 1997.

FERREIRA, I. M. Bioma cerrado: caracterização do subsistema de vereda. In: ENCONTRO REGIONAL DE GEOGRAFIA, 9., 2005, Porto Nacional. Anais... Porto Nacional: EREGEO, 2005.

FERREIRA, I. M. Modelos geomorfológicos das veredas em ambiente de cerrado. Espaço em Revista, Catalão, v. 7/8, n. 1, p. 7-16, jan./dez. 2006.

GOODEY, B.; GOLD J. Geografia do comportamento e da percepção. Belo Horizonte: EdUFMG, 1986.

GUERRA, A. T. Dicionário geológico-geomorfológico. Rio de Janeiro: FIBGE, 1978.

JARDÍ, M. Paisage: una síntesis geográfica. Revista de Geografia, Barcelona, v. 24, p. 4360, 1990.

LOPES, D. L. Diário de campo: o registro da reconstrução da natureza e da cultura. In: WHITAKER, D. C. A. Sociologia rural: questões metodológicas emergentes. Presidente Venceslau: Letras à Margem, 2002, p. 135-142.

MACIEL, A. B. C.; LIMA, Z. M. C. O conceito de paisagem: diversidade de olhares. Sociedade e Território, Natal, v. 23, n. 2, p. 159-177, jul./dez. 2011.

MARIA, V. R. B. Inventário florístico das áreas úmidas do Rio Formoso, município de Bonito, MS. Bonito: Fundação Neotrópica do Brasil, 2009.

MARTINS, R. A. Aplicação do geoprocessamento no estudo integrado das áreas de preservação permanentes nos municípios de Morrinhos e Caldas Novas-GO. 2010. 171f. Dissertação (Mestrado) - Universidade Federal de Goiás, Catalão, 2010.

MEIRELLES, M. L.; GUIMARÃES, A. J. M.; OLIVEIRA, R. C.; ARAÚJO, G. M.; RIBEIRO, J. F. Impactos sobre o estrato herbáceo de áreas úmidas do cerrado. In: AGUIAR, L. M. S.; CAMARGO, A. J. A. Cerrado: ecologia e caracterização. Planaltina: Embrapa Cerrados, 2004, p. 41-68.

MORAES, A. C. R. Geografia: pequena história crítica. São Paulo: Hucitec, 1990. 
SANTOS, J. C. V.; CARNEIRO, V. A.; SILVA, L. G.; DRUCIAKI, V. P.

Paisagens e empirismo, elementos constitutivos das experiências em Geografia: um estudo sobre as veredas do chapadão de Catalão (Goiás)

OLIVEIRA FILHO, A. T. Floodplain "murundus" of Central Brazil: evidence for the termite - origin hypothesis. Journal of Tropical Ecology, Cambridge, v. 8, n. 1, p. 1-19, 1992.

OLIVEIRA FILHO, A. T.; FURLEY, P. A. Monchão, cocuruto, murundu. Ciência Hoje, São Paulo, n. 11, p. 30-37, 1990.

OLIVEIRA, L. Contribuição dos estudos cognitivos à percepção geográfica. Rio Claro: UNESP, 1977.

OLIVEIRA, L.; MACHADO, L. M. C. P. Paisagem \& paisagens. In: ENCONTRO

INTERDISCIPLINAR SOBRE O ESTUDO DA PAISAGEM, 3., 1998, Rio Claro. Anais... Rio Claro: UNESP, 1998.

RIBEIRO, A. G. Paisagem e organização espacial na região de Palmas e Guarapuara. 1989. 336f. Tese (Doutorado) - Universidade de São Paulo, São Paulo, 1989.

RIBEIRO, A. G. Teoria da paisagem aplicada ao desenvolvimento rural sustentado. In: ENCONTRO DE GEÓGRAFOS DA AMÉRICA LATINA, 8., 2001, Santiago. Anais... Santiago: EGAL, 2001.

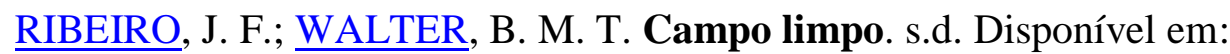

<http://www.agencia.cnptia.embrapa.br/Agencia16/AG01/arvore/AG01_37_911200585233.h

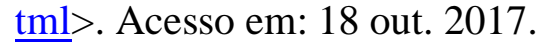

ROSA, J. G. Grande sertão: veredas. Rio de Janeiro: José Olympio, 1956.

ROSS, J. L. S. Geomorfologia, ambiente e planejamento. São Paulo: Contexto, 2000.

ROUGERIE, G. Geografia das paisagens. São Paulo: Difusão Europeia, 1971.

SANTOS, M. Metamorfoses do espaço habitado. São Paulo: Hucitec, 1997.

SANTOS, R. J. Pesquisa empírica e trabalho de campo: algumas questões acerca do conhecimento geográfico. Sociedade \& Natureza, Uberlândia, n. 11, n.p., jan./dez. 1999.

STEINKE, V. A. Uso integrado de dados digitais morfométricos (altimetria e sistema de drenagem) na definição de unidades geomorfológicas no Distrito Federal. 2007. 229f. Tese (Doutorado) - Universidade de Brasília, Brasília, 2007.

STURZA, J. A. I. Paisagem e organização espacial na bacia do Ribeirão Ponte de PedraMT. 1999. 104f. Dissertação (Mestrado) - Universidade Estadual Paulista, Presidente Prudente, 1999.

TUBELIS, D. P. Veredas and their use by birds in the cerrado, South America: a review. Biota Neotropica, Campinas, v. 9, n. 3, p. 363-374, 2009. 
SANTOS, J. C. V.; CARNEIRO, V. A.; SILVA, L. G.; DRUCIAKI, V. P.

Paisagens e empirismo, elementos constitutivos das experiências em Geografia: um estudo sobre as veredas do chapadão de Catalão (Goiás)

UFG. Universidade Federal de Goiás. Novas espécies de plantas são descobertas por pesquisadora da Regional Jataí. s.d. Disponível em: <https://jatai.ufg.br/n/90652-novasespecies-de-plantas-sao-descobertas-por-pesquisadora-da-regional-jatai >. Acesso em: 18 out. 2017.

VELOSO, M. P. Visita técnica - uma investigação acadêmica. Goiânia: Kelps, 2000.

WIKIPÉDIA. Microrregião de Catalão. s.d. Disponível em: <https://pt.wikipedia.org/wiki/Microrregi\%C3\%A3o_de_Catal\%C3\%A3o >. Acesso em: 22 out. 2017.

\section{Autores}

Jean Carlos Vieira Santos - Possui Graduação, Mestrado e Doutorado em Geografia pela Universidade Federal Uberlândia (UFU). Atualmente é Professor do Programa de PósGraduação em Geografia (PPGEO/Unidade Cora Coralina) e do Programa de Pós-Graduação em Territórios e Expressões Culturais no Cerrado (PPG-TECCER/Anápolis) da Universidade Estadual de Goiás (UEG).

Vandervilson Alves Carneiro - Possui Graduação em Geografia pela Universidade Estadual Paulista Júlio de Mesquita Filho (UNESP); Mestrado e Doutorado em Geografia pela Universidade Federal de Goiás (UFG). Atualmente é Professor do Programa de PósGraduação em Geografia (PPGEO/Unidade Cora Coralina) da Universidade Estadual de Goiás (UEG).

Lorranne Gomes da Silva - Possui Graduação em Geografia pela Universidade Estadual de Goiás (UEG); Mestrado e Doutorado em Geografia pela Universidade Federal de Goiás (UFG). Atualmente é Professora do Programa de Pós-Graduação em Geografia (PPGEO/Unidade Cora Coralina) da Universidade Estadual de Goiás (UEG).

Vinícius Polzin Druciaki - Possui Graduação em Geografia pela Universidade Estadual do Centro-Oeste (UNICENTRO); Mestrado em Geografia pela Universidade Estadual de Maringá (UEM) e Doutorado em Geografia pela Universidade Estadual Paulista Júlio de Mesquita Filho (UNESP). Atualmente é Professor do Programa de Pós-Graduação em Geografia (PPGEO/Unidade Cora Coralina) da Universidade Estadual de Goiás (UEG).

Artigo recebido em: 08 de maio de 2018.

Artigo aceito em: 23 de dezembro de 2018. Artigo publicado em: 30 de dezembro de 2018. 